\title{
RANGE EXPANSION OF THE HOUSE FINCH INTO THE PRAIRIE PROVINCES
}

JEAN BANCROFT, 306-200 Tuxedo Boulevard, Winnipeg, Manitoba, R3P 0R3 and ROBERT J. PARSONS, 68 Thatcher Drive, Winnipeg, Manitoba. R3T 2L3

The House Finch is a comparative newcomer to Canada; it entered the country from the United States from two distinct sources. The native western population has spread north into British Columbia $^{17}$ and the introduced eastern population is currently invading Ontario and points eastward. In this article, the authors trace the spread into the Prairie Provinces.

Bancroft's first experience with the House Finch, in Honolulu, Hawaii, in the 1980s, stimulated her interest in this adaptable bird and provided the impetus for this article. 5

\section{Range Expansion Toward the Prairie Provinces}

The original range of the House Finch was in the southwestern United States and Mexico. 2 The 1931 edition of the American Omithologists' Union (AOU) Check-list gives Oregon as the northern boundary east to central Idaho and western Wyoming. ${ }^{2}$ It is recorded that in the Pacific northwest the range did not extend as far as Walla Walla, Washington, until after $1910 .^{17} \mathrm{~A}$ few years later it was found to be common in that state to within $66 \mathrm{~km}$ south of the Canadian border. ${ }^{17}$

The House Finch first appeared in 1935 in southern British Columbia where "a small breeding colony was first noticed in Penticton in that year"; the expansion of this finch into this province is well described by Edwards and Stirling. ${ }^{17}$ More recent spread has been modest and generally limited to the major river valleys where human habitation is found. "Edwards and Stirling mention that "man with his buildings and gardens, fields and irrigation, appears to have created new and suitable physical habitat for the House Finch in both the valleys extending northward from the Columbia Basin and the dry parts of the Pacific Coast."17

Along with northward expansion, there was also range extension to the east. The 1983 edition of the AOU Check-list gives northern Idaho and extreme wesiern Montana, as the House Finch range's northeastern boundary. ${ }^{3}$ This is a gain of $400 \mathrm{~km}$ to the northeast in 50 years.

This finch was first introduced into eastern North America at Long Island, New York, by cage bird dealers in 1940 for the pet trade. ${ }^{18}$ With the threat of prosecution for this illegal activity, dealers released the birds into the wild. ${ }^{26}$ The House Finch has been dramatically increasing its range across the United States ever since. ${ }^{1,19,26}$ This spread has been accompanied by great increases in numbers. As an example, Dennis states that since 1975 he has had large numbers of these birds at his feeders in Maryland. ${ }^{12}$

The birds reached South Carolina in 1966 and the Mississippi River in 
1979. ${ }^{13}$ Up to that time, expansion had been strongest in a southwesterly direction. This was aided by settlements along river valleys. Additionally, the Great Lakes acted as an impediment to straight westward expansion. By the early 1980s the House Finch had reached the southem tip of Lake Michigan and the first Illinois nest was found in
$1982 .^{27}$ After rounding the south end of Lake Michigan, the northward spread was quite rapid, with the first nests having been found in Wisconsin in 1986. 8 ,32 House Finches are now "regular" in eastern South Dakota, although with no proof of nesting. ${ }^{25}$

During the past decade the House

Table 1: Alberta Reports of the House Finch (see Appendix 1 for references)

\begin{tabular}{|c|c|c|}
\hline Location & Date & Observer(s) \\
\hline Topaz Lake, Jasper & 29 May 1944 & I. McT. Cowan ${ }^{4}$ \\
\hline Waterton Lakes N.P. & June 1964 & W. Salt \& A.L. Wilk ${ }^{18}$ \\
\hline Seebe, Kananaskis & & \\
\hline Experimental Station & 2 June 1966 & T.S. Sadler \& M.T. Myers ${ }^{17}$ \\
\hline Kananaskis & 1971 & T.S. Sadler ${ }^{15}$ \\
\hline Calgary & 10 March-21 April 1973 & R.J. Butot ${ }^{3}$ \\
\hline Calgary & 29 September-14 October 1973 & R.J. Butot ${ }^{8}$ \\
\hline Vermilion Lakes & 21 May 1975 & J. Wolford ${ }^{9}$ \\
\hline Calgary & 28 April-8 May 1975 & W. Amos, R.J. Butot \& R. Jones ${ }^{14}$ \\
\hline Kananaskis & 1976 & T.S. Sadler \& M.T. Myers ${ }^{16}$ \\
\hline Busby & 13 August-3 September 1978 & V., B. \& L. Lang \& B. George ${ }^{10}$ \\
\hline Calgary & May 1980 & P. Sherrington \& A. Wiseley ${ }^{20}$ \\
\hline Canmore & 7 June 1981 & R. Barclay \& D. Collister ${ }^{2}$ \\
\hline Canmore & 3,6 \& 7 June 1981 & $\begin{array}{l}\text { G. Holroyd, K. Vantighem \& } \\
\text { J. Steeves }{ }^{6}\end{array}$ \\
\hline Calgary & 9 December 1981-9 May 1982 & R.J. Butot ${ }^{19}$ \\
\hline Calgary & 19-24 April 1982 & R.J. Butot \& J. McCullough ${ }^{19}$ \\
\hline Canmore & 18 May 1982 & G.L. Holroyd ${ }^{19}$ \\
\hline Calgary & 4 December 1982 & D. Collister \& D. Matthews ${ }^{19}$ \\
\hline Calgary & 14 July-27 September 1983 & J. McCullough ${ }^{11}$ \\
\hline Busby & 19 September 1983 & V. Young ${ }^{21}$ \\
\hline *Sundre & $\begin{array}{l}17 \text { April } 1984 \\
\text { (two birds) }\end{array}$ & F. Haug ${ }^{\top}$ \\
\hline Calgary & 2, 5-7 July 1984 & J. Podlubney ${ }^{12}$ \\
\hline Calgary & $\begin{array}{l}7 \text { July } 1984 \\
\text { (one feeding a young cowbird) }\end{array}$ & G. Simpson ${ }^{12}$ \\
\hline Calgary & $7-12$ July 1984 & J. McCullough $^{7}$ \\
\hline Edmonton & 22 December 1985 & D. Ealey \& P. Marklevitz ${ }^{5}$ \\
\hline Claresholm & October 1985-April 1986 & R. \& J. Attwell ${ }^{1}$ \\
\hline *Claresholm & $\begin{array}{l}\text { November 1986-May } 1987 \\
\text { (two birds) }\end{array}$ & R. \& J. Attwell ${ }^{1}$ \\
\hline *Claresholm & $\begin{array}{l}13 \text { December } 1987 \\
\& \text { most of winter } \\
\text { (two birds) }\end{array}$ & G. Norgard ${ }^{13}$ \\
\hline Claresholm & October 1988-April 1989 & R. \& J. Attwell ${ }^{1}$ \\
\hline Claresholm & 16 December 1989 - & \\
\hline & 3 January 1990 & G. Norgard ${ }^{13}$ \\
\hline *Claresholm & $\begin{array}{l}9 \text { August } 1990 \\
\text { (two birds) }\end{array}$ & R. \& J. Attwell ${ }^{1}$ \\
\hline Claresholm & 24 August - 22 September 1990 & G. Norgard ${ }^{13}$ \\
\hline Claresholm & 26 - 30 October 1990 & G. Norgard ${ }^{13}$ \\
\hline
\end{tabular}

* More than one bird 
Finch has spread into southeastern Canada from the eastern United States. The first Ontario record was from Prince Edward County on 27 August 1972, but it was not until 1978 that two nests were discovered in Niagara-on-the-Lake. ${ }^{31,20}$ The major concentrations of House Finches seem to occur along the shores of Lakes Erie and Ontario. ${ }^{10}$ They are now found throughout urban and agricultural areas of southem Ontario. Habitat constraints will probably preclude significant further range expansion, although there is still potential for a great increase in numbers.

The nearest nesting population of House Finches to the eastern Prairie Provinces is at Fargo, North Dakota, where they have been suspected or proven to nest in the summers of 1987 , 1988, 1989 and 1990. 7,8,21,24 The Fargo population, when it first appeared, was isolated from both the eastern and western populations. Now, however, it is apparently almost continuous with the eastern population in South Dakota and Minnesota.

\section{The House Finch in the Prairie Provinces}

In Tables 1-3, reported sightings of House Finches are shown in detail. Most of the appearances in the Prairie Provinces, except where otherwise noted $\left(^{*}\right)$, have been of single birds, usually at or near feeders. For the sake of completeness, all known sightings are listed even at the risk of including some misidentified birds. Some of these have been questioned by various provincial authorities, though they may well be valid sightings. Many would be accepted if the observer(s) would take time to write up a description and submit it to their provincial records committee or equivalent, such as a provincial museum.

Table 2: Manitoba Reports of the House Finch (see Appendix 1 for references)

\begin{tabular}{|c|c|c|}
\hline Location & Date & Observer(s) \\
\hline Stonewall & 29 March-9 April 1983 & K. Gardner \& R. Koes ${ }^{10}$ \\
\hline $\begin{array}{l}\text { Oakbank (incorrectly } \\
\text { reported as Winnipeg) }\end{array}$ & 17 April 1983 & G. Grieef ${ }^{8}$ \\
\hline Stonewall & 2 May 1983 & K. Gardner ${ }^{8}$ \\
\hline Altona & 15 - 16 May 1984 & H. Wiens, et al. ${ }^{2}$ \\
\hline Oakbank & 2 September 1984 & G. Grieef \& R. Koes ${ }^{12}$ \\
\hline Winnipeg & 29 April 1985 & R. Tkachuk ${ }^{3}$ \\
\hline Oakbank & 5 October 1985 & G. Grieef ${ }^{9}$ \\
\hline Winnipeg & 27 April 1986 & L. Jansson ${ }^{4}$ \\
\hline Winnipeg & 14 - 15 May 1987 & N. Hansley ${ }^{5}$ \\
\hline Altona & 18 May 1988 & M. Krueger ${ }^{6}$ \\
\hline Winnipeg & 14 May 1989 & R. Nero \& R. Parsons ${ }^{7}$ \\
\hline *Altona & $\begin{array}{l}18 \text { April } 1990 \\
\text { (two birds) }\end{array}$ & M. Krueger ${ }^{11}$ \\
\hline *Winnipeg & $\begin{array}{l}17-21 \text { May } 1990 \\
\text { (three birds) }\end{array}$ & B. Lavender, et al. ${ }^{11}$ \\
\hline Winnipeg & 21 May 1990 & G. Derochers ${ }^{11}$ \\
\hline Winnipeg & 21 May 1990 & D. $\operatorname{Cox}^{11}$ \\
\hline Winnipeg & 21 May 1990 & D. Hatch ${ }^{11}$ \\
\hline *Winnipeg & $\begin{array}{l}10-28 \text { August } \\
1990 \text { (two birds) }\end{array}$ & R. \& M. Prociuk ${ }^{12}$ \\
\hline Winnipeg & 13 October 1990 & M. Siepman ${ }^{1}$ \\
\hline Carberry & $\begin{array}{l}17 \text { November- } \\
4 \text { December } 1990\end{array}$ & B. \& R. Anderson ${ }^{12}$ \\
\hline
\end{tabular}

* More than one bird 
Table 3: Saskatchewan Reports of the House Finch (see Appendix 1 for references)

$\begin{array}{ll}\text { Location } & \text { Date } \\ \text { Saskatoon } & \text { 15 October 1959 } \\ \text { *Regina } & \text { 26 April 1973 } \\ & \text { (three birds) } \\ \text { Saskatoon } & \text { 6 February 1976 } \\ \text { Fort Qu'Appelle } & \text { 29 April 1978 } \\ \text { Somme } & \text { 30 April-1 May 1987 } \\ \text { *Little Nut Lake } & \text { 10- 11 April 1988 } \\ & \text { (two pairs) } \\ \text { Regina } & \text { 23-24 April 1990 } \\ \text { Weybum } & \text { 12 October 1991 }\end{array}$

Observer(s)

* More than one bird

\section{Discussion}

As noted, the House Finch has spread throughout the populated areas of British Columbia and Ontario. It seems to show no inclination to inhabit areas beyond those of reasonably dense, human habitation. Because of this tendency, direct spread into the Prairie Provinces from either British Columbia or Ontario is unlikely, as the mountains of the former and the boreal forests of the Canadian shield of the latter form an inhospitable barrier.

Both the eastern and the western populations of the House Finch are in a position to spread into the Prairie Provinces from the United States. The western population is within $200 \mathrm{~km}$ of extreme southwestern Alberta. As a result, the Alberta sightings almost certainly originate from this population. Although continentally the western population does not appear to be exhibiting the dramatic explosion of the eastern, or the number of extralimital sightings, there is no doubt that the number of reported sightings in Alberta has gained some momentum since the beginning of the 1980s.

Notwithstanding the Fargo population, the breeding range of the eastern House Finch is still at least $500 \mathrm{~km}$ away from the eastern Prairie Provinces. However, given the tendency of extralimital occur49(3). September 1991 rences of birds from this population, it is safe to say that some, if not all, of the sightings from Manitoba can be attributed to this population. ${ }^{9}$ This argument is strengthened by the fact that the timing of the first sightings in Manitoba coincide with the northward spread of the breeding range along the west side of Lake Michigan. This marked the beginning of eastern House Finches being within "striking distance" of Manitoba, as House Finches are not inclined to long-distance flights.

The Saskatchewan sightings are more problematic. The sightings up to and including the one in Fort Qu'Appelle in 1978 , would almost certainly be likely to have a western origin, based on geographical proximity. The more recent sightings could conceivably have come from either population. The Saskatchewan sightings, like the Manitoba ones, are mostly of birds inclined to appear in spring and remain only briefly. The Alberta ones, by contrast, have appeared at just about any season and, in some cases, have remained for considerable periods. This similarity in pattern between Manitoba and Saskatchewan may be suggestive of a common origin, but it must be stressed that this is purely speculation.

Extralimital sightings, by themselves, do not constitute a range expansion. For definite range expansion by the House 


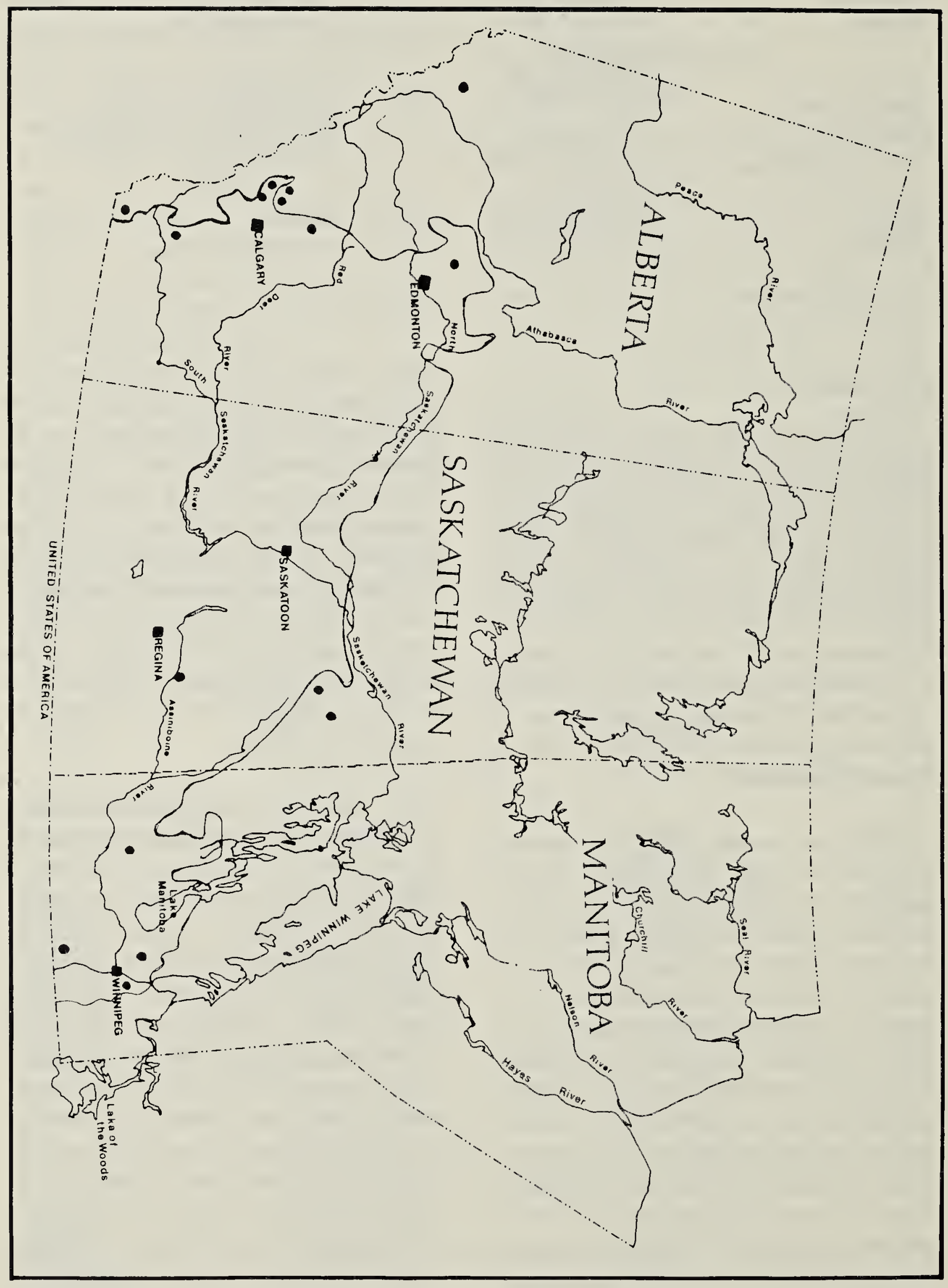

Figure 1. Reported sightings of the House Finch in the Prairie Provinces as indicated in Tables 1-3. 
Finch into the prairie provinces, nesting must occur. So far, there are no definite nesting attempts known from anywhere in the Prairie Provinces, but there are one or two suggestive sightings.

The most suggestive observation of nesting is the one from Calgary on 7 July 1984 of a male finch feeding a fledgling cowbird. While this strongly supports the theory that the House Finch nested nearby and fledged the cowbird, it does not prove it. Healthy adult birds of many species, especially if thwarted from normal breeding activities (e.g., in this case, possibly lacking a mate), are known to indulge in various activities related to nesting, such as feeding juvenile birds, even to the point of feeding fledglings of different species. ${ }^{30}$ Furthermore, juvenile cowbirds are especially able to solicit feeding from adult birds of other species. Finally, Skutch has documented the phenomenon of feeding juvenile birds of other species by the House Finch. ${ }^{30}$

A second suggestive sighting is the one of two pairs of House Finches, if correctly identified, at Little Nut Lake, Saskatchewan, on 10-11 April 1988. As there is no further evidence of their continued presence, however, this is not highly suggestive of nesting.

Although nesting has not yet been proven for the Prairie Provinces, observers should be on the lookout for nests. This is especially the case since the normal nesting ranges of both the eastern and western populations are getting closer to our area and also because the House Finch has, on more than one occasion, been found to nest in areas away from the known breeding range. ${ }^{19,21}$ Finding nests should not be too difficult, given the species' preference for nesting near human habitation, especially in suburban areas. This would be a worthwhile project for the backyard birdwatcher in order to help increase our knowledge of this species.
The House Finch is very versatile in its nesting preferences, e.g., tree cavities, bird boxes, building ledges ${ }^{23}$ hanging flower pots; ${ }^{6}$ as well as in different species of trees; ${ }^{4,34}$ and vines. ${ }^{19}$ Graham reports that House Finches nesting around Guelph, Ontario, show a preference for Colorado spruce (Picea pungens). ${ }^{22}$ As this tree is a popular ornamental planting throughout the Prairie Provinces, it should aid the spread of the House Finch throughout the region.

One question that remains, however, is whether or not the House Finch can withstand our climate, i.e. our winters. Throughout its regular wintering range, the western House Finch population is not found in any area with winters as cold as those of the Canadian Prairies. Similarly, the eastern population has yet to move into areas with winter temperatures comparable to ours. It has, however, proven that it can survive, persist and increase at Fargo which has fairly severe winters. This supports the theory that it may be able to withstand our winters. Similarly, individual birds have successfully overwintered at feeders in Alberta. It should be noted that Alberta has the mildest winters of the three Prairie Provinces, but in theory, this should mean that the House Finch can survive throughout the agricultural areas of this region.

If they prove unable to withstand our winters, House Finches will have to rely on a strategy of winter withdrawal in order to persist here. As already mentioned, the House Finch is not noted for its ability to migrate long distances. This would likely curtail any great penetration into the Prairie Provinces, and result in a status of occasional nesting, but with high winter mortality and much dependence on recruitment from southerly sources. This is characteristic of birds such as the Northern Cardinal on the northern periphery of its range. ${ }^{20,33}$ 
assume that the House Finch will fail to adapt. It has been defying predictions about the limits of the northern expansion of its range for some time. Bock and Lepthien point out that Salt would have predicted that the House Finch could not survive and persist on Long Island. ${ }^{9,29}$ Clearly, this was incorrect. Mundinger and Hope predicted that the latitude of Lake Ontario might prove to be the northern limit of the House Finch's eastern range. ${ }^{26}$ This, too, has been greatly surpassed, as House Finches are present and increasing in Quebec, New Hampshire, Vermont, Maine and New Brunswick. ${ }^{14,15,16}$ Bock and Lepthien hypothesize that evolutionary change may be at work. ${ }^{9}$ This theory is supported by Aldrich and Weske who say that "the case of the House Finch parallels that of the House Sparrow (Passer domesticus) in its rapid evolutionary change after introduction and spread into new environments." 1 On this basis, the House Finch should do very well in the Canadian Prairie Provinces.

\section{Acknowledgements}

Appreciation is expressed to Robert W. Nero for his encouragement and constructive criticism of an earlier draft of this paper, to $\mathrm{R}$. Wayne Campbell for his help and access to the Archives of The Royal Victoria Museum; to Brooks Wildlife Centre; to Alberta Bird Atlas Project, Provincial Museum of Alberta, Edmonton; to Ross D. Dickson, Grace Norgard, and Ruth and Jason Attwell, for information in connection with some Alberta sightings; to C. Stuart Houston and Frank H. Brazier for particulars of Saskatchewan sightings; to R. Terry Sprague who provided statistics regarding Ontario records; to Herbert W.R. Copland who provided access to the files of the Manitoba Omithological Records Committee; to Rudolf F. Koes who provided information and assistance regarding some Manitoba sightings; to Heather Neil who prepared the map.

The authors are also indebted to the numerous observers whose sightings form the basis of much of this report.
1. ALDRICH, J.W. and J. WESKE. 1978. Origin and evolution of the eastern House Finch population. The Auk 95:528-536.

2. AMERICAN ORNITHOLOGISTS' UNION. 1931. Check-list of North American birds, 4th edition. American Ornithologists' Union, Lancaster, Pa. 526 pp.

3. 1983. Check-list of North American birds, 6th edition. American Omithologists' Union, Washington, D.C. $877 \mathrm{pp}$.

4. BANCROFT, J. 1989. Another view on the House Finch. Nature Society News, November 1989. Grigg sville, Ill.

5. 1990. House Finch behaviour in Hawaii. Nature Society News, December 1990. Griggsville, Ill.

6. BERGER, A.J. 1981. Hawaiian birdlife. 2nd edition. University Press of Hawaii. $260 \mathrm{pp}$.

7. BERKEY, G. 1988. Northem Great Plains Region. Am. Birds 42:1307.

8. - 1990. Northem Great Plains Region. Am. Birds 44:1151.

9. BOCK, C. and L. LEPTHIEN. 1976. Growth in the eastem House Finch population, 1962-1971. Am. Birds 30:791-792.

10. CADMAN, M.D., P.F.J. EAGLES and F.M. HELLEINER. 1986. Atlas of the breeding birds of Ontario. Federation of Ontario Naturalists and the Long Point Bird Observatory. University of Waterloo Press. pp. 492-3.

11. CANNINGS, $R$. and $R$. and $S$. CANNINGS. 1987. Birds of the Okanagan Valley, British Columbia. Royal British Columbia Museum, Victoria, B.C. 420 pp.

12. DENNIS, J.V. 1988. Summer bird feeding. The Audubon Workshop, Inc. Northbrook, Ill. 136 pp.

13. 1989. Jury still out on the House Finch. Nature Society News, October 1989. Griggsville, Ill.

14. DRENNAN, SUSAN RONEY (ed.). 1988. Eighty-eighth Christmas Bird Count. Am. Birds 42:503-1198.

15. 1989. Eighty-eighth Christmas Bird Count. Am. Birds 43:549-1236.

16. 1990. Eighty-eighth Christmas Bird Count. Am. Birds 44:515-1050. 
17. EDWARDS, R.Y. and D. STIRLING. 1961. Range expansion of the House Finch into British Columbia. Murrelet 42:38-42.

18. ELLIOTT, J.J. and R.S. ARBIB. 1953. Origin and status of the House Finch in the eastem United States. The Auk 70:30-37.

19.GILL, D.E. and W.E. LANYON. 1965. Establishment, growth, and behaviour of an extralimital population of House Finches at Huntington, New York. Birdbanding 36:1-14.

20.GODFREY, W.E. 1986. The birds of Canada. Natl. Mus. Nat. Sci., Ottawa. 595 pp.

21. GOLLOP, B. 1987. Prairie Provinces Region. Am. Birds 41:1455.

22. GRAHAM, D.S. 1988. House Finch nestsite selection at Guelph, Ontario. The Condor. 90:58-60.

23.HARRISON, H.H. 1975. A field guide to birds' nests in the United States east of the Mississippi River. Houghton Mifflin Co., Boston. 257 pp.

24. LAMBETH, D. O. 1990. Northern Great Plains Region. Am. Birds 44:113.

25._ 1990. Northern Great Plains Region. Am. Birds 44:450.

26.MUNDINGER, P. and S. HOPE. 1982. Expansion of the winter range of the House Finch: 1947-79. Am. Birds 36:347-353.

27.PETERJOHN, B.G. 1982. Middlewestern Prairie Region. Am. Birds 36:984.

28. — 1988. Middlewestem Prairie Region. Am. Birds 42:1208.

29.SALT, G. 1952. The relation of metabolism to climate and distribution in three finches of the genus Carpodacus. Ecological Monographs 22:121-152.

30. SKUTCH, A. 1987. Helpers at birds' nests: a worldwide survey of cooperative breeding and related behavior. University of Iowa Press, Iowa City. 298 pp.

31.SPRAGUE, R.T. and R.D. WEIR. 1984. The birds of Prince Edward County, Ontario. 2nd edition. Kingston Field Natu ralists, Kingston, Ontario. p. 142.

32. TESSEN, D.D. 1989. Westem Great Lakes Region. Am. Birds 43:1320.

33. UDVARDY, M.D.F. 1977. The Audubon Society field guide to North American 49(3). September 1991 birds, westem region. Alfred A. Knopf, N.Y. 855 pp.

34. VAN RIPER, C. III. 1976. Aspects of House Finch breeding biology in Hawaii. The Condor 78:224-229.

\section{Appendix 1:}

Sources of information for sightings listed in the Tables 1, 2 and 3.

\section{Table 1}

1. ATTWELL, R. \& J. Pers. comm.

2. BARCLAY, R., and D. COLLISTER. 1981. Calgary birds June to August 1981. Pica 2:104-110.

3. BUTOT, R.J. 1973. First verified report of a House Finch in Calgary. Calgary Field Nat. 5:10-11.

4. COWAN, I. McT. 1955. Birds of Jasper Nat. Park. Wildl. Mgmt. Bull. Ser. 2, 8:1-67.

5. DRENNAN, SUSAN RONEY (ed.). 1988. Eighty-eighth Christmas Bird Count. Regional Summaries. Am. Birds 40:635.

6. GOLLOP, B. J. 1981. Prairie Provinces Region. Am. Birds 35:950-952.

7. 1984. Prairie Provinces Region. Am. Birds 38:927.

8. HOUSTON, C. S. 1974. Northem Great Plains Region. Am. Birds 28:70.

9. Walford 1976. Interim rep. for Banff National Park.

10. LANG, V. (ed.) 1978. Proceedings of the Alberta Omithological Records Committee. Alberta Nat. 9:78-79.

11. McCULLOUGH, J. 1983. Calgary Birds. Calgary, p.55.

12.—— 1984. Calgary Birds. Calgary, p.63.

13. NORGARD, G. Pers. comm.

14.PINEL, H.W., and R.J. BUTOT. 1978. Highlights of bird observations in the Calgary area, Alberta, 1971-1977. Blue Jay 36:159-163.

15.SADLER, T.S. 1971. Birds of the Kananaskis region. Univ. of Calgary Environ. Sci. Centre Publication.

16.SADLER, T.S. and M.T. MYERS. 1976. Alberta birds, 1961-1970, with reference to migration. Alberta Natural Hist. Occ. 
Paper No. 1. pp. 1-314.

17. No Date. A review of birds. Unpub. rep. 197 pp.

18.SALT, W. and A.L. WILK. 1966. Birds of Alberta, p. 432.

19. WEDGWOOD, J. 1982. Prairie Provinces Region. Am. Birds 36:864-866.

20. WISELEY, A.N. 1980. May species count for 1980 - birds and mammals. Alberta Nat. 11 (suppl. 1):21-33.

21. YOUNG, V. 1982. House Finch near Dunstable, Alberta. Alberta Nat. 13:146.

Table 2

1. HATCH, David. "Chickadee Notes," Winnipeg Free Press, 27 October 1990.

2. GOLLOP, B. J. 1984. Prairie Provinces Region. Am. Birds 38:926.

3. 1985. Prairie Provinces Region. Am. Birds 39:316.

4. 1986. Prairie Provinces Region. Am. Birds 40:488.

5. 1987. Prairie Provinces Region. Am. Birds 41:450.

6. 1988. Prairie Provinces Region. Am. Birds 42:451.

7. 1989. Prairie Provinces Region. Am. Birds 43:497.

8. HARRIS, W.C. 1983. Prairie Provinces Region. Am. Birds 37:884.

9. 1986. Prairie Provinces Region. Am.
Birds 40:131.

10.KOES, R.F. 1985. Additions to the Manitoba bird list (1975-1984). Blue Jay 43:224-231

11.KOES, R. F. and P. Taylor. 1990. Prairie Provinces Region. Am. Birds 44:447.

12. Manitoba Ornithological Records Committee (MORC) files.

Table 3

1. BARD, F. 1973. House Finches sighted in Regina. Blue Jay 32:48.

2. BARR K. 1990. House Finch at Regina, Saskatchewan. Blue Jay 48:167.

3. CALLIN E.M. 1980. Birds of the Qu'Appelle, 1857-1979. SNHS Spec. Pub. \#13.68 pp.

4. HOOPER, D.F. 1990. House Finch and American woodcock at Somme. Blue Jay $48: 47$.

5. Pers. comm. Fide C.S. Houston.

6. O'NEILL, P. 1976. House Finch - an old friend. Blue Jay 34:127-128.

7. SAUNDERS, L.G. 1959. Birds in an apple tree. Blue Jay 17:158.

8. KOES, R.F. and P. TAYLOR. 1991. Prairie Provinces Region. Am. Birds 45:119-120.

Names are important, of course, and it is worth while to make a good deal of fuss over them because otherwise two observers would not know whether or not they were talking about the same creature, and endless confusion would result. But it is a great pity that all information - and, too often, all curiosity - should stop with what is really only a preparation for learning something. J.W. Krutch, 1952. The Desert Year. William Sloane. 